\title{
An Update on the Tissue Renin Angiotensin System and Its Role in Physiology and Pathology
}

\author{
Ali Nehme ${ }^{1}{ }^{(}$, Fouad A. Zouein ${ }^{2} \mathbb{C}$, Zeinab Deris Zayeri ${ }^{3}$ and Kazem Zibara ${ }^{4, *}$ \\ 1 EA4173, Functional genomics of arterial hypertension, Univeristy Claude Bernard Lyon-1 (UCBL-1), \\ 69008 Lyon, France; ali.hassan.nehme@gmail.com \\ 2 Department of Pharmacology and Toxicology, Heart Repair Division, Faculty of Medicine, \\ American University of Beirut, Beirut 11-0236, Lebanon; fz15@aub.edu.lb \\ 3 Thalassemia \& Hemoglobinopathy Research Center, Health Research Institute, Ahvaz Jundishapur \\ University of Medical Sciences, Ahvaz, Iran; zeynabderisgenetice@gmail.com \\ 4 PRASE, Biology Department, Faculty of Sciences-I, Lebanese University, Beirut, Lebanon \\ * Correspondence: kzibara@ul.edu.lb
}

Received: 10 February 2019; Accepted: 26 March 2019; Published: 29 March 2019

\begin{abstract}
In its classical view, the renin angiotensin system (RAS) was defined as an endocrine system involved in blood pressure regulation and body electrolyte balance. However, the emerging concept of tissue RAS, along with the discovery of new RAS components, increased the physiological and clinical relevance of the system. Indeed, RAS has been shown to be expressed in various tissues where alterations in its expression were shown to be involved in multiple diseases including atherosclerosis, cardiac hypertrophy, type 2 diabetes (T2D) and renal fibrosis. In this chapter, we describe the new components of RAS, their tissue-specific expression, and their alterations under pathological conditions, which will help achieve more tissue- and condition-specific treatments.
\end{abstract}

Keywords: renin-angiotensin-aldosterone system; tissue; expression; physiology

\section{Introduction}

In its classical view, RAS was defined as an endocrine system involved in blood pressure regulation and body electrolyte balance. However, RAS is now considered a "ubiquitous" system that is expressed locally in various tissues and exerts multiple paracrine/autocrine effects involved in tissue physiology and homeostasis [1]. Indeed, RAS plays key roles in cellular growth, proliferation, differentiation, migration, and apoptosis, in addition to extracellular matrix (ECM) remodeling and inflammation [2].

Alterations in RAS expression were shown to be involved in multiple diseases including atherosclerosis, cardiac hypertrophy, type 2 diabetes, and renal fibrosis [2-4]. On the other hand, RAS-blocking agents, such as angiotensin converting enzyme (ACE) inhibitors and AT1 receptor blockers (ARBs), have been shown to be effective in the management of hypertension-related cardiovascular diseases and end-organ damage [5]. Therefore, it is necessary to know the components of RAS, their tissue-specific expression, and how they may change under pathological conditions. In this review, we discuss classical and novel components of RAS, their role in local tissue physiology, and their changes under specific pathological conditions. A better understanding of local tissue RAS expression and regulation will help achieve more tissue- and condition-specific treatments.

\section{An Overview of RAS}

In its classical view, RAS includes successive enzymatic reactions resulting in the conversion of the "inactive" substrate angiotensinogen (AGT), into the active peptide angiotensin II (Ang-II) which binds to its specific membrane receptors and elicits cellular effects [2] (Figure 1 and Table 1). AGT is a 
glycoprotein continuously produced by the liver. In addition, it is differentially expressed in multiple other tissues, including heart, blood vessels, kidneys, and adipose tissue [2]. AGT production can be induced by several stimuli, including inflammation, insulin, estrogen, glucocorticoids, thyroid hormone, and Ang-II [6].

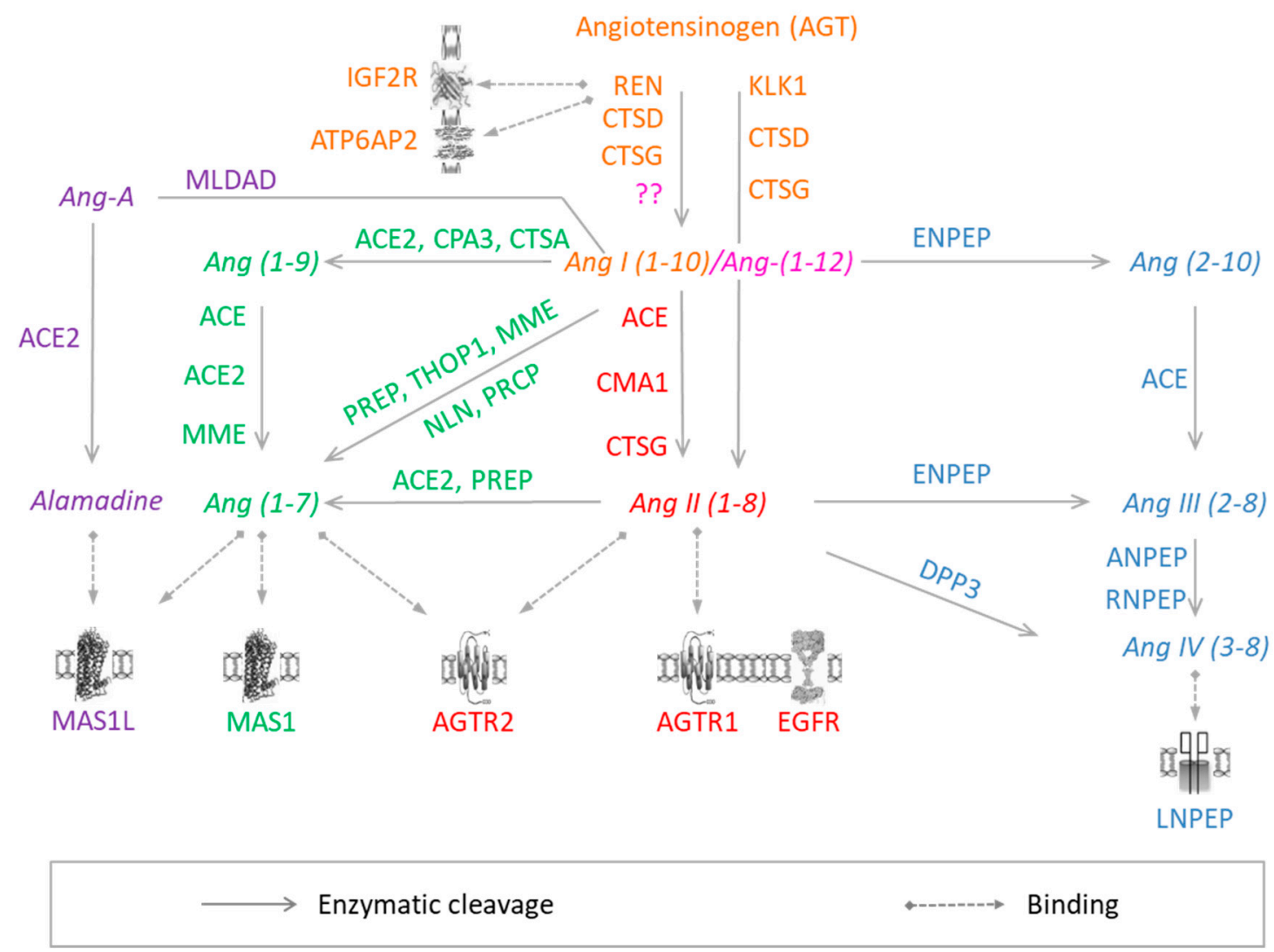

Figure 1. RAS components. Colors correspond to different arms of RAS: Orange, Angiotensin-I; pink, Angiotensin-(1-12); red, Angiotensin-II; green, Angiotensin-(1-7); Blue, Angiotensin III/VI; violet, Alamandine. Proteins are represented by the corresponding official gene symbols. The figure was adapted from Nehme et al. 2015 [7].

In the plasma, AGT is converted into the decapeptide angiotensin-I (1-10) (Ang-I) by renin (Figure 1 and Table 1), a tightly regulated enzyme produced by the juxtaglomerular cells (JG) [8]. In fact, this step is considered the rate limiting step of Ang-II release in the circulation [8]. Renin is synthesized as an inactive enzyme that is cleaved by microsomes to produce prorenin [9]. Prorenin is then either released as inactive precursor or converted by a variety of proteases into active intracellular renin that is stored in granules of the JG cells. Active renin is released into the circulation by JG cells via an exocytic process and upon a stimulus $[8,10]$ by different mechanisms including Ang-II negative feedback [10].

Ang-I is further processed by angiotensin-converting enzyme (ACE), a membrane-bound exopeptidase, to release the vasoactive octapeptide angiotensin II (1-8) (Ang-II) (Figure 1 and Table 1). Besides Ang-II production, ACE can degrade a number of vasodilating peptides including Ang-(1-7), bradykinin, and kallikrein, thus playing a central role as a vasopressor enzyme $[2,8]$. Moreover, ACE can activate cellular signaling when bound to its inhibitors (ACEIs) and bradykinin, leading to increased ACE and COX2 production [11]. 
Table 1. Extended renin-angiotensin-aldosterone system components.

\begin{tabular}{|c|c|c|}
\hline Gene Symbol & Gene Description & Gene ID \\
\hline $\mathrm{ACE}$ * & angiotensin I converting enzyme (peptidyl-dipeptidase A) 1 & 1636 \\
\hline ACE2 & angiotensin I converting enzyme (peptidyl-dipeptidase A) 2 & 59272 \\
\hline $\mathrm{AGT}^{*}$ & angiotensinogen (serpin peptidase inhibitor, clade A, member 8) & 183 \\
\hline AGTR1 * & angiotensin II receptor, type 1 & 185 \\
\hline AGTR2 & angiotensin II receptor, type 2 & 186 \\
\hline ANPEP & alanyl (membrane) aminopeptidase & 290 \\
\hline ATP6AP2 & ATPase, $\mathrm{H}+$ transporting, lysosomal accessory protein 2 & 10159 \\
\hline CMA1 & chymase 1 , mast cell & 1215 \\
\hline CPA3 & carboxypeptidase A3 (mast cell) & 1359 \\
\hline CTSA & cathepsin $\mathrm{A}$ & 5476 \\
\hline CTSD & cathepsin D & 1509 \\
\hline CTSG & cathepsin $\mathrm{G}$ & 1511 \\
\hline DPP3 & dipeptidyl-peptidase 3 & 10072 \\
\hline EGFR & epidermal growth factor receptor & 1956 \\
\hline ENPEP & glutamyl aminopeptidase (aminopeptidase A) & 2028 \\
\hline IGF2R & insulin-like growth factor 2 receptor & 3482 \\
\hline KLK1 & kallikrein 1 & 3816 \\
\hline LNPEP & leucyl/cystinyl aminopeptidase & 4012 \\
\hline MAS1 & MAS1 oncogene & 4142 \\
\hline MME & membrane metallo-endopeptidase & 4311 \\
\hline NLN & neurolysin (metallopeptidase M3 family) & 57486 \\
\hline PREP & prolyl endopeptidase & 5550 \\
\hline $\mathrm{REN}^{*}$ & renin & 5972 \\
\hline RNPEP & arginyl aminopeptidase (aminopeptidase B) & 6051 \\
\hline THOP1 & thimet oligopeptidase 1 & 7064 \\
\hline AKR1C4 & aldo-keto reductase family 1 , member $\mathrm{C} 4$ & 1109 \\
\hline AKR1D1 & aldo-keto reductase family 1 , member D1 & 6718 \\
\hline CYP11A1 & cytochrome $\mathrm{P} 450$, family 11 , subfamily A, polypeptide 1 & 1583 \\
\hline CYP11B1 & cytochrome P450, family 11 , subfamily $\mathrm{B}$, polypeptide 1 & 1584 \\
\hline CYP11B2* & cytochrome P450, family 11 , subfamily B, polypeptide 2 & 1585 \\
\hline CYP17A1 & cytochrome P450, family 17 , subfamily A, polypeptide 1 & 1586 \\
\hline CYP21A2 & cytochrome P450, family 21 , subfamily A, polypeptide 2 & 1589 \\
\hline GPER & G protein-coupled estrogen receptor 1 & 2852 \\
\hline HSD11B1 & hydroxysteroid (11-beta) dehydrogenase 1 & 3290 \\
\hline HSD11B2 * & hydroxysteroid (11-beta) dehydrogenase 2 & 3291 \\
\hline $\mathrm{NR} 3 \mathrm{C} 1$ & nuclear receptor subfamily 3 , group $C$, member 1 (glucocorticoid receptor) & 2908 \\
\hline $\mathrm{NR} 3 \mathrm{C} 2$ * & nuclear receptor subfamily 3 , group C, member 2 (Mineralocorticoid receptor) & 4306 \\
\hline
\end{tabular}

* Classical RAS components.

Ang-II is a biologically active peptide that mediates its effects via the angiotensin-II type 1 receptor (AT1R) [12] (Figure 1). Ang-II was originally known as a circulating hormone that regulates blood pressure and electrolyte balance by acting on vascular contraction, aldosterone secretion, renal sodium handling, sympathetic activity, and vasopressin release [2]. However, molecular studies have shown that AT1R activation can exert long-term genetic effects, in addition to rapid short term effects at the cellular level [13]. Like most other GPCRs, AT1R undergoes rapid desensitization and internalization after agonist stimulation to avoid extensive chronic activation [2].

One of the major effects of Ang-II is the stimulation of aldosterone synthase, CYP11B2, expression in the adrenal cortex [14] (Figure 1 and Table 1). Aldosterone has emerged as an essential regulator of blood pressure in mammals, and has been associated with a variety of diseases in humans [15]. Aldosterone acts in a variety of tissues through its mineralocorticoid receptor (MR) to influence extracellular fluid volume, blood pressure and salt exchange, but may also lead to pathological consequences, mainly tissue fibrosis and oxidative stress [16]. 


\section{The Concept of Tissue RAS}

Several lines of evidence support the concept of extended RAS that includes multiple synonymous enzymatic pathways for the generation of different angiotensin peptides which exert their effects in a tissue- and condition-specific manner [17]. These pathways may explain the dual role of RAS as not only a circulating hormone, but also a tissue-specific regulatory system serving autocrine, paracrine, and even intracrine functions.

The first demonstration of the presence of a local tissue RAS was in 1971, where a renin-like activity was found in the brain of dogs and which was independent of renin found in the kidney and plasma [18]. This finding was then supported by the identification of Ang-I-like peptides in dog brain with variable molecular weights [19]. Since then, local angiotensin pathways and their physiological importance were elucidated in different tissues including the heart, blood vessels, kidney, brain, adipose tissue, adrenal gland, pancreas, liver, reproductive system, lymphatic tissue, placenta and the eye (Table 2) $[2,20,21]$. In these tissues, local RAS acts independently from systemic RAS in a paracrine and autocrine manner, but may still interact with systemic RAS to exert endocrine effects [2]. A study conducted by Lau et al. showed a local angiotensin-generating system in the exocrine pancreas. Their data showed the existence of an islet angiotensin-generating system that has an important role in physiological regulation of glucose-induced insulin secretion [22]. In addition, recent studies have reported the expression of renin and angiotensinogen genes and identified their products at many local tissue sites, which further supports the concept of multiple tissues synthesizing RAS components [23]. In fact, multiple studies have described tissue RAS and reported its role in various tissues such as cardiac, vascular and renal tissues, which have the majority of ACE in the body. It seems that tissue RAS has long-term effects on cardiovascular function and structure, while its alteration can cause pathologic conditions [24].

Table 2. The physiological and pathophysiological role of RAS in different tissues.

\begin{tabular}{ccc}
\hline Tissue & Physiological Role of RAS & Associated Diseases \\
\hline Blood vessel & Vasomotor regulation, oxidative & metabolism \\
Heart & Vasomotor tone, fibrotic regulation, & Hypertension, atherosclerosis \\
oxidative metabolism & Heart failure, cardiac hypertrophy and \\
Kidney & Blood pressure regulation & Chronic kidney disease \\
CNS & Sympathetic regulation of blood pressure & Hypertension \\
Adipose tissue & Adipogenesis & Insulin resistance and obesity \\
Eye & Aqueous humor dynamics & Glaucoma and diabetic retinopathy \\
Liver & Glucose metabolism & Glucose intolerance and fibrosis \\
\hline
\end{tabular}

\subsection{Angiotensin-I}

Apart from Renin, several enzymes were found to cleave angiotensinogen into Ang-I, such as cathepsin D (CTSD), cathepsin G (CTSG), and tonins [25] (Figure 1). In addition, studies have shown that three main receptors can be bound and activated by renin, which are: renin-binding protein (RnBP), mannose 6-phosphate/insulin-like growth factor II (M6P/IGFII) receptor and the renin/prorenin receptor (R/PR) [26] (Figure 1 and Table 1). Although RnBP is known to be a renin inhibitor, the latter two are known to increase renin catalytic activity and activate intracellular signaling [20]. R/PR binding is supposed to induce full non-proteolytic activation of prorenin by a conformational change, through which prorenin active site is exposed [26]. The interaction between $\mathrm{R} / \mathrm{PR}$ and prorenin is species-specific, which may explain the lack of rat prorenin activation by human R/PR [27]. 
The concept of local RAS was initially challenged by the fact that renin was considered the rate-limiting specific enzyme to cleave AGT into Ang-I [28]. However, renin mRNA and/or activity was detected in several extra-renal tissues, including the vascular wall [29], cardiac [30], adipose [31], and eye tissues [32]. In addition, M6P/IGFII receptor, encoded by the IGF2R gene, contribute to the uptake and activation of M6P-containing prorenin from the circulation at different tissues and in a variety of cells including cardiomyocytes [33], fibroblasts, VSMCs, and ECs [26,33]. On the other hand, the P/PR was shown to be expressed and active in diverse tissues, including the kidney, vascular wall, brain, and the eye. Alterations in R/PR are associated with pathologies such as glomerulosclerosis, diabetes, hypertension, neovascularization and inflammation [26].

In fact, renin is considered the rate limiting enzyme for the generation of Ang-I in plasma, whereas in tissues, enzymes other than renin are thought to regulate Ang-I generation [34]. Of importance is CTSD, which is a ubiquitous lysosomal aspartyl protease [35] that was shown to provide an alternative angiotensin production pathway after myocardial infarction, and hence falsely increase clinical plasma renin activity determinations [36]. Cathepsin D knockdown by siRNA led to more than a two-fold reduction in intracellular and extracellular Ang-I and Ang-II production by VSMCs under both normal and high glucose concentrations [37]. Interestingly, however, silencing of tissue plasminogen activator (tPA) gene, previously associated with Ang-II production [38], moderately increased intracellular Ang-I and Ang-II levels in VSMCs only under high glucose concentrations, while strongly decreased Ang-I and Ang-II levels in the media [37]. However, a consensus on the renin-compensatory activity of CTSD has not been reached yet due to the low specificity and efficiency of CTSD, which has been found to only metabolize AGT under acidic conditions [39,40].

Despite the importance of this rate limiting step in RAS, little effort has been made to further support local Ang-I generation from renin or renin-like enzymes. Therefore, further studies should be performed to identify local mechanisms involved in angiotensinogen cleavage, either through renin recruitment from the circulation, or through local renin-independent enzymatic reactions.

\subsection{Angiotensin (1-12)}

One of the recent important discoveries in RAS is the identification of the Angiotensin (1-12) peptide (Ang-(1-12)), which may serve as an alternative precursor for the production of bioactive angiotensin peptides, independent from Ang-I production [41]. Ang-(1-12) was first isolated by Nagata et al. from rat small intestine, and was shown to induce constriction of aortic strips ex vivo and to raise blood pressure in rats when infused intravenously [41]. Both the vasoconstrictor and pressor responses to Ang-(1-12) were abolished by ACE inhibitors (ACEI) and AT1R blockers (ARBs), which suggest a renin-independent pathway for angiotensin peptides production [41,42]. Despite the differences in amino acid sequence of rat and human Ang-(1-12), Ferrario et al. showed cardiac production of Ang-(1-12) in a rat model expressing human AGT [43].

In addition, compelling evidence suggests that Ang-(1-12) is a major source for local Ang-II production in the central nervous system. Endogenous neutralization of Ang-(1-12) using antibodies directed against the C-terminal end of Ang-(1-12) into a lateral cerebral ventricle of (mRen2)27 transgenic hypertensive rats prompted blood pressure reduction that was associated with a transient anti-dipsogenic behavior [44]. Central effects of Ang-(1-12) were later shown to be mediated via the Ang-II/AT1R axis in the solitary tract nucleus and hypothalamic arcuate nucleus [45-47]. Ang-(1-12) was also shown to be present abundantly in a wide range of rat organs and tissues, including heart ventricular myocytes, small intestine, spleen, kidneys, and liver [41]. Lower levels were also found in the medial layer of intracoronary arteries and vascular endothelium [48]. Despite the increase in plasma renin activity following low-salt feeding, the levels of Ang-I, Ang-II, and Ang-(1-12) in plasma and various tissues remained unchanged [49], which suggests that Ang-(1-12) metabolism is regulated in a manner that is independent of circulating renin activity.

Studies on Ang-(1-12) clearly demonstrate species-specific, tissue-specific, and condition-specific metabolism that favors one pathway or enzyme, over the others [17]. For instance, Jessup et al. 
showed that Ang-(1-12) immunoreactivity was detected in both the heart and kidney of spontaneously hypertensive rats (SHR) and Wistar-Kyoto (WKY) rats. However, tissue measurements by radioimmunoassay showed higher cardiac and lower renal levels of Ang-(1-12) in SHR, compared with WKY rats [48]. It was shown that Ang-(1-12) was cleaved by ACE to generate both Ang-I and Ang-II in rat serum, independent of renin participation [50]. On the other hand, the same team showed that Ang-(1-7) and Ang-(1-4) were the main products of Ang-(1-12) metabolism in renal cortical membranes of rats, which were abolished by neprilysin inhibition [50]. In addition, myocytes of WKY rats were shown to sequester Ang-(1-12) in culture, which was mainly metabolized by ACE and membrane metallo-endopeptidase (MME) [51]. Interestingly, the uptake and metabolism were higher in cardiomyocytes obtained from SHR rats with a predominant effect of chymase in these cells [52]. On the other hand, chymase was shown to be the major enzyme contributing to Ang-(1-12) cleavage in an isolated heart model of cardiac ischaemia-reperfusion injury in Sprague-Dawley rats [53]. ACEI, however, but not chymostatin, inhibited circulatory Ang-(1-12) production in both SHR and WKY rats ${ }^{42}$.

Ang-(1-12) production and metabolism have raised concerns about the possible role of this peptide in mitigating the effects of renin and ACE inhibitors in the treatment of heart failure, which warrant further studies to identify tissue-specific RAS metabolic targets for disease treatment.

\subsection{Angiotensin-II}

In addition to the ACE-dependent cleavage of Ang-I, Ang-II can also be produced by the direct cleavage of AGT by cathepsin G [54], tonin, and kallikrein, or through Ang-I cleavage by chymase and cathepsin $G^{216}$ (Figure 1 and Table 1). Of importance, chymase, a serine protease that is highly specific to the Phe ${ }^{8}$-His ${ }^{9}$ bond [17] of Ang-I, was shown to be more active than ACE in generating Ang-II in human heart [55] and diabetic kidneys [56].

In addition to AT1R (Figure 1 and Table 1), Ang-II also acts through AT2R, a seven transmembrane receptor that acts mainly through $\mathrm{Gi}$ and tyrosine phosphatases to exert inhibitory actions on cellular responses mediated by AT1R, mainly by inhibiting cell growth and proliferation while promoting cell differentiation, in addition to vasodilation and reducing blood pressure [57].

Ang-II was thought for a long time to be only a circulating peptide, exerting its effects through endocrine mechanisms. However, many studies identified Ang-II in several tissues and showed that it was produced locally independent of systemic RAS. The first demonstration of tissue Ang-II was in the arterial wall in sheep in 1980 [58]. Studies quantifying tissue Ang-II synthesis, using radiolabeled angiotensin, revealed that Ang-II in the heart, kidney, and adrenal gland [59,60] almost completely originates from local synthesis, both under normal and pathological conditions [60,61]. ACE was shown to be expressed in multiple tissues, including vascular endothelium, renal proximal tubular endothelium, heart, lung, small intestine, colon, activated macrophages, and several regions of the brain [62], where physiologic effects of ACE are the result of tissue rather than circulating ACE activity [63].

ACE is generally considered the main Ang-II-forming enzyme in the circulation. However, in tissues, various serine proteases were shown to play a role in Ang-II generation [53]. Not only chymase, but also trypsin [64] and kallikrein [65] serine proteases were shown to generate Ang-II in vitro and in vivo in ischemic dog hearts, ischemic human hearts, and even in normal healthy individuals during exercise [66]. In fact, chymase has been a focus of interest because of its specificity and potency in the human cardiovascular system [55,67].

Ang-II may exert local paracrine or autocrine effects through its locally expressed AT1 and AT2 receptors (Figure 1 and Table 1). AT1R was found to be expressed in several adult tissues, including blood vessels, heart, kidney, adrenal glands, and liver [2]. On the other hand, AT2R is mainly expressed in fetal tissue and decreases through fetal development [2] to be restricted to certain tissues, mainly the heart, vessels, brainstem, liver, and kidney [68]. At the tissue level, AT1R and AT2R exert opposite effects; therefore, the final local effects of Ang-II are defined by the combined net 
result obtained from the activation of both receptors. For instance, AT1R induces vasoconstriction and sodium retention in the kidney whereas AT2R promotes vasodilation and natriuresis [69]. On the other hand, in the gastrointestinal tract, AT2R opposes the actions of AT1R in sodium and water absorption, which contributes to the regulation of the finely tuned sodium transport in this tissue [70]. In general, AT2R stimulates protein dephosphorylation, which counterbalances protein phosphorylation induced by AT1R, thus, affecting the signaling pathways inside the cell, leading mainly to opposite cellular actions [69]. Despite this general "antagonistic" view of AT2R, certain studies on cardiac myocytes showed that its overexpression may complement, rather than antagonize, the AT1R effects in cellular hypertrophy [71,72]. Similarly, AT1R and AT2R synergistically act to induce adipogenesis and lipid storage in adipose tissue, wherein AT1R inhibit lipolysis, while AT2R induces the expression of lipogenic enzymes [73]. Interestingly, this adds a new level of complexity to RAS in which the effects of the system depend not only on the "inter-molecular" balance between the antagonistic arms, but also on the "intra-molecular" balance of the levels of the same molecule in certain cells under specific conditions.

Ang-II is the most studied pathway in RAS and additional research on it would open new avenues in understanding the complexity of the system and inter-pathway interactions.

\subsection{Angiotensin-(1-7)}

Ang-(1-7) was first discovered in rat brains in 1983 by Tonnaer and his colleagues [74]. However, at that time, it was thought to be an inactive peptide. The importance of Ang-(1-7) emerged in 1988 when it was found to be the major Ang-I-derived peptide in the presence and absence of ACE inhibition [75]. Ang-(1-7) was initially thought to exert its hypotensive effects in a bradykinin-dependent manner [76]. However, it was later demonstrated that Ang-(1-7) opposes the vasoconstrictive and proliferative actions of AT1R-mediated Ang-II actions [2,17]. In fact, the discovery of Ang-(1-7) and its effects lead to the belief that RAS local actions are mainly driven by the balance between the vasoconstrictor/proliferative and vasodilator/anti-proliferative actions of Ang-II and Ang-(1-7), respectivley [2].

Ang-(1-7) can be formed by different enzymes and pathways (Figure 1 and Table 1). The most potent and well known Ang-(1-7)-generating enzyme is ACE2 (angiotensin-I converting enzyme 2), which can generate Ang-(1-7) directly from Ang-II, or indirectly from Ang-I through Ang-(1-9) intermediate $[77,78]$. In fact, the former pathway is more favorable because the affinity of ACE2 to Ang-II is 400-folds greater than that to Ang-I [79]. Ang-(1-9) can be generated from Ang-I by the action of ACE2, cathepsin A (CTSA) [80], or carboxypeptidase A3 (CPA3), and then cleaved to form Ang-(1-7) by ACE [77], ACE2, or neprilysin (MME) (Figure 1 and Table 1). Alternatively, Ang-(1-7) can also be formed directly from Ang-I by prolylendopeptidase (PREP), thimet Oligopeptidase 1 (THOP1), [81] and Neurolysin (NLN) or from Ang-II cleavage by ACE2, PREP, and prolylcarboxipeptidase (PRCP) [2,79] (Figure 1 and Table 1).

In fact, ACE2 levels and the ACE/ACE2 ratio is generally considered a reference for Ang-(1-7) production. However, ACE2 is restricted to certain tissues and cells such as endothelial cells of the heart, kidneys, and testes [82]. In addition, the contribution of alternative enzymes in the production of Ang-(1-7) should be considered. For instance, metallopeptidase activity accounts for almost all Ang (1-7) production in atrial homogenate preparations, whereas Ang-II was produced equally by ACE and chymase while cathepsin A was responsible for 65\% of the liberated Ang (1-9) [80]. This indicates that local angiotensin peptides production depends as well on the activity of "alternative" enzymes at the tissue level.

Ang-(1-7) exerts its effects mainly through the Mas receptor (MasR) (Figure 1 and Table 1). MasR was first described as Ang-(1-7) receptor in 2003, where its deletion abolished the binding of Ang-(1-7) to mouse kidneys, accompanied with the loss of Ang-(1-7)-induced relaxation [83]. By binding to MasR, Ang-(1-7) may induce many effects, antagonizing those of Ang-II/AT1R, such as vasodilation, inhibition of cell growth, anti-thrombosis, and anti-arrhythmogenic effects [84]. 
In addition, it was shown that MasR may antagonize AT1R in vitro and in vivo by forming a hetero-dimer with the AT1R, thus blocking the latter's activity [85]. Moreover, Ang-(1-7) can act on the AT2R (Figure 1 and Table 1), which exerts very similar effects to those induced by MasR [86]. In addition, emerging evidences raised controversies on the specificity of MasR to Ang-(1-7). Recently, MasR was shown to be stimulated by multiple other molecules such as Neuropeptide FF, Alamandine, Angiotensin III, Angiotensin IV, and Angioprotectin. Similarly, independent studies demonstrated the absence of MAS1 activation after Ang-(1-7) treatment in human mammary arteries from patients undergoing coronary revascularization surgery, splanchnic vessels from cirrhotic liver of human and rats and aorta from Sprague-Dawley rats [87].

Ang-(1-7) is present in the circulation, in addition to several other tissues and organs including the heart, blood vessels, kidney and liver [88], where it exerts local paracrine and autocrine actions. The alteration in circulatory and tissue Ang-(1-7) levels were shown to be associated with several diseases, including hypertension preeclampsia, hypertrophic myocardial disease, cognitive heart disease, myocardial infarction (MI), chronic kidney disease (CKD), and hepatic cirrhosis [2]. For instance, $A C E 2^{-/}$mice developed age-dependent cardiomyopathy with increased oxidative stress, neutrophilic infiltration, inflammatory cytokine, and collagenase levels, mitogen-activated protein kinase (MAPK) activation and pathological hypertrophy [89]. These effects were inhibited by irbesartan, an AT1R blocker (ARB), which indicates a critical role for ACE2 in the suppression of Ang-II-mediated heart failure. In addition, a recent study suggested an important role for the ACE/ACE2 imbalance in the pathogenesis of severe acute pancreatitis where the ratio of pancreatic ACE2 to ACE expression was significantly reduced and paralleled the severity of the disease [90]. In another study, a reduction in ACE/ACE2 ratio was shown to be associated with acute respiratory distress syndrome, which was prevented by Ang-(1-7) or ARB treatment [91]. Recent studies have supported a metabolic role for the Ang-(1-7)/MasR arm in the liver and its counter-regulatory action to Ang-II/AT1R that interferes in several steps of intracellular insulin signaling arm in the pathophysiology of liver diseases [92]. Indeed, Ang-(1-7) has been shown to ameliorate glucose tolerance and to enhance insulin sensitivity, while Mas receptor has been described as an essential component of the insulin receptor signaling pathway [93]. Of interest, ACE2 treatment has been shown to ameliorate liver fibrosis through reduction of hepatic Ang-II levels concomitant with increased concentrations of Ang-(1-7) in liver tissue [94-96]. Moreover, Ang-(1-7)/MasR axis agonists may also play a role in the treatment of CKD by controlling the inflammatory response and fibrosis in kidney tissue [97].

Of note, high concentrations of Ang-(1-7) exerts biphasic effects on $\mathrm{Na}^{+}-, \mathrm{K}^{+}$-ATPase activity in a dose dependent manner by inducing similar effects to those induced by Ang-II at high concentrations, independent of MasR and AT2R, probably through the AT1R [98]. However, in the presence of Ang-II, Ang-(1-7) antagonized the stimulatory effects of Ang-II on $\mathrm{Na}^{+}, \mathrm{K}^{+}$-ATPase activity through a A779-sensitive receptor [99]. On the other hand, Ang-(1-7) infusion or MasR deficiency enhanced renal damage in models of renal insufficiency by aggravating the inflammatory response through NF- $\mathrm{kB}$ [100]. In contrast, another study showed that Ang-(1-7) suppressed inflammation by inhibiting the NF- $k B$ pathway in rats with permanent cerebral ischaemia [101].

Taken together, these studies suggest that Ang-(1-7) exerts cell-specific effects based on its concentrations, available receptors, angiotensin peptides, and the physiological state of the tissue.

\subsection{Angiotensin-III/-IV}

Arterial concentration of Ang-III (hexapeptide 2-8) was first documented in 1980 in sheep, and accounted for $42 \%$ of that of Ang-II [58]. Ang-III is generated from Ang-II by the removal of the first amino terminus aa by Aminopeptidase A (ENPEP) [8] (Figure 1 and Table 1). In addition, it can be generated from Ang-I by a two-steps pathway involving ENPEP and ACE, respectively [102]. Studies have shown that Ang-III exerts similar, but less potent, actions as compared to Ang-II [2,103], by acting on AT1R and AT2R, with higher affinity to the former [104]. Indeed, Ang-III was shown to 
increase blood pressure, vasopressin and aldosterone release, in addition to inducing inflammatory genes expression $[2,103]$.

Ang-III in turn can be converted into Ang-IV (pentapeptide 3-8) by the action of the aminopeptidase N (ANPEP) [105], and possibly aminopeptidase B (RNPEP) [106] (Figure 1 and Table 1). Ang-IV acts through its Angiotensin type 4 receptor (AT4R), which is the insulin-regulated membrane aminopeptidase (IRAP). The latter is a type II integral membrane spanning protein belonging to the M1 family of aminopeptidases that is expressed in several tissues, including the brain, adrenal gland, kidney, lung, liver, and heart [107] (Figure 1 and Table 1).

Recent studies have shown that certain local Ang-II-mediated effects could be attributed to Ang-III. For example, Padia et al. showed that the conversion of Ang-II to Ang-III is critical for AT2R-mediated natriuresis in Sprague-Dawley rats [104]. Similarly, in Wistar rats, the Ang-II-mediated enhancement in baroreceptor heart reflex was abrogated in the presence of ENPEP inhibitor, indicating that Ang-III is the active angiotensin peptide involved in central blood pressure regulation [108]. On the other hand, Handa et al. showed that intrarenal injection of Ang I, Ang-II, or Ang-III induce dose-dependent vasoconstriction in Sprague-Dawley rats. However, Ang-IV or Ang-(3-10) injection produced a dose-dependent rapid vasoconstriction, lasting for seconds, followed by a transient vasodilatation, lasting for minutes [109]. This indicates that RAS induces peptide-specific effects at the tissue level.

The major effects of AT4R activation are thought to be in the brain where it can enhance learning and memory [107]. However, the mechanism by which Ang-IV exerts its effects through IRAP is still not clear [110]. One suggestion is that Ang-IV inhibits the catalytic activity of IRAP, thereby extending the half-life of its neuropeptide substrates. Another suggestion is that it may modulate glucose uptake by modulating GLUT4 trafficking. Others suggest that it may act directly on cellular mechanisms by inducing cellular signaling after its binding [110]. Ang-IV in the brain was also shown to be implicated in regulating blood pressure by acting on the AT1R [111], which was shown to mediate several Ang-IV effects. Indeed, Ang-IV mediates pressure and renal vasoconstrictor effects in mice via AT1a receptor whereas AT4R is not involved [112]. Finally, Ang-IV-mediated non-prostaglandin renal vasodilatory activity was found to be linked to renal vascular AT1R [109].

The Ang-III/Ang-IV axes have added a new level of complexity to the system and identified novel mechanisms by which Ang-II may exert its effects. This needs to be further studied to elucidate possible flows in the interpretation of the effects of Ang-II agonists and to identify possible mechanisms that would improve Ang-II antagonists' mode of action.

\subsection{Angiotensin A/Alamandine/MrgD}

Ang-A is a recently discovered angiotensin peptide detected in the plasma of patients with end-stage renal disease, where Ang-A/Ang-II ratio was found to be higher compared to healthy individuals [113]. Ang-A is an octapeptide with the sequence Ala-Arg-Val-Tyr-Ile-His-Pro-Phe, which can be produced from Ang-II by conversion of the first amino acid, aspartic acid, into alanine [113]. Ang-A can bind to AT1R and AT2R with equal affinity as Ang-II [114]. Intravenous and intrarenal administration of Ang A induced dose-dependent increase in blood pressure and renal vasoconstrictor responses in normotensive and spontaneously hypertensive rats [114,115]. In isolated perfused rat kidney, Ang-A induced smaller vasoconstrictive effects compared to Ang-II, which were inhibited using AT1R inhibitor, but not AT2R inhibitor [113,114].

In fact, the importance of Ang-A is increasing due to its junctional position in the system. Despite its vasoconstrictive and pro-proliferative actions, Ang-A is also a precursor of alamandine, a recently discovered peptide identified in rats, mice, and humans [116]. Alamandine can also be produced from Ang-(1-7) by ACE2 and was shown to produce several physiological actions that resemble those produced by Ang-(1-7) including vasodilation, antifibrotic, antihypertensive, and CNS effects, independent of MasR and AT2R [116]. The effects of alamandine were shown to be mediated through the activation of a specific receptor, the member D of Mas1-related G-protein-coupled receptor (MasDR) [116], which has been recently demonstrated to also be an alternative receptor to 
Ang-(1-7) [117]. Interestingly, alamandine was shown to exert opposite effects in central nervous system where microinjection of alamandine into the rostral ventrolateral medulla of rats induced a vasopressor effect, whereas its administration into the caudal ventrolateral medulla elicited a vasodilatory effect. Of importance, similar effects were obtained after Ang-(1-7) injection [116]. On the other hand, in control but not diseased blood vessels, alamandine enhanced acetylcholine-mediated vasodilation in normal thoracic aorta and the iliac artery, whereas it reduced it in the renal artery [118]. Interestingly, these effects were absent in blood vessels from atherogenic rabbits, which also showed a reduced vasoconstrictive response toward Ang-A.

The finding of MasDR receptor has added another level of complexity into RAS, especially with regards to the anti-inflammatory Ang-(1-7) axis. This warrants further studies that may explain additional interactions and would balance between the different axes of RAS.

\subsection{Other Angiotensin Peptides}

Ang-(1-9) was considered for a long time as an intermediate peptide with no biological significance. However, recent evidence suggests that Ang-(1-9) can exert several effects in vivo and in vitro independent of Ang-(1-7)-mediated MasR activation, possibly through AT2R [2]. Indeed, a new study showed that Ang-(1-9) exerts beneficial cardiovascular effects via the AT2R in hypertensive rats independent of blood pressure modulation, where it ameliorated structural alterations (hypertrophy and fibrosis) and oxidative stress in the heart and aorta and improved cardiac and endothelial function [2]. These effects were inhibited by an AT2R antagonist, but not a MasR one. On the contrary, in another study on rats, Ang-(1-9) enhanced thrombosis, decreased plasma concentrations of tissue plasminogen activator (tPA), and increased the levels of its inhibitor (PAI-1) through indirect activation of AT1R [119]. These effects were reversed by selective antagonists to AT1R, but not to that of Ang-(1-7).

Ang-(3-7) is an angiotensin peptide that was shown to bind to AT4R, with lower affinity compared to Ang-IV, leading to important effects in the brain and kidney [2]. Ang-(3-7) can be produced by cleavage of Ang-(1-7), Ang-II, or Ang-IV by aminopeptidases or carboxypeptidases [2]. Administration of Ang (3-7) intracerebroventricularly (i. c. v.) significantly enhanced learning and behavioral activity in rats [120]. Co-treatment withthe ARB, losartan, only affected learning ability, without altering the behavioral activity. This suggests that Ang (3-7) is an active peptide that exerts its effects through different receptors, one of which is AT1R [120]. Moreover, Ang-(1-7) induced inhibitory effects on the energy-dependent solute transport in proximal tubules of the rat kidney [121] were shown to be mediated by the metabolism of Ang-(1-7) into Ang (3-7), by binding to AT4R [121]. Such results may raise questions about the previously described "direct" effects of certain angiotensin peptides.

\section{Conclusion and Future Directions}

The concept of tissue RAS could be defined as a specific combination of RAS enzymes that are locally expressed in a tissue, which results in the production of a specific quantitative and qualitative combination of peptides that can bind to their corresponding locally expressed receptors, thus leading to a locally balanced paracrine/autocrine effect that plays a role in tissue physiology and homeostasis. A change in local RAS expression will consequently lead to alterations in the balance obtained, and thus, to pathophysiological consequences (Figure 2). In this regard, studies on RAS need to be shifted from the one peptide-one pathway approach, toward a more general approach that considers the tissue-specific pathways and their respective local and systemic interactions. Indeed, the knowledge obtained from the former approach may lead to misleading conclusions that rely on the used model, with a lack of information on other pathways that may balance the effect of the pathway in question. Therefore, for a better understanding of the "real" global physiological effects of RAS, it is necessary to measure the different components of RAS in a specific tissue, under specific physiological conditions. 


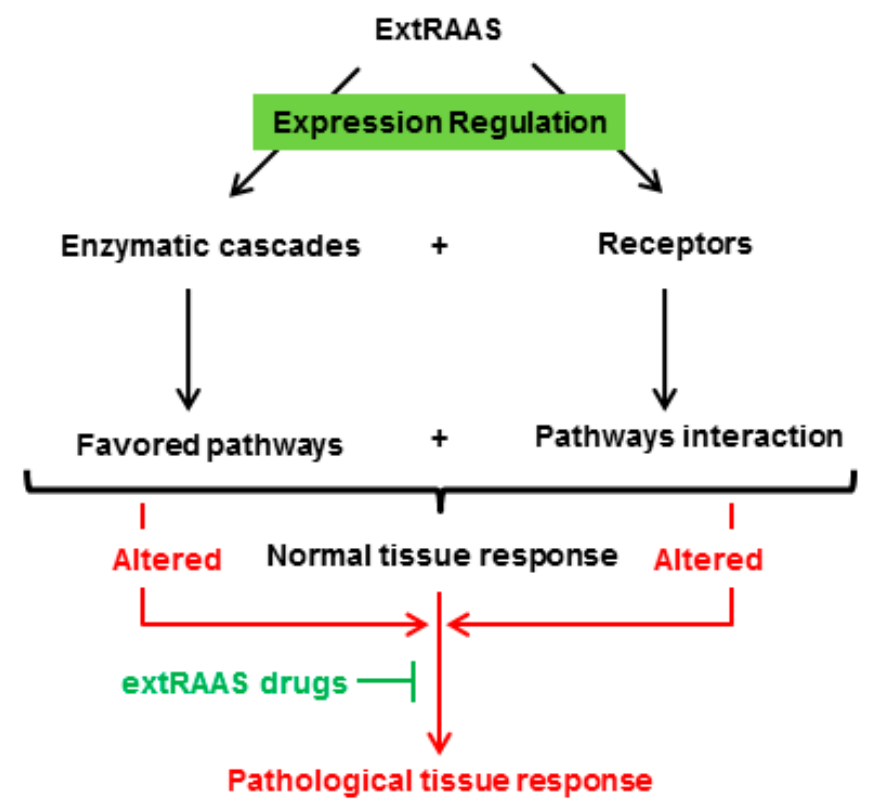

Figure 2. A specific combination of locally expressed RAS enzymes in a tissue results in the production of a specific combination of peptides that can bind to their corresponding receptors, leading to a locally balanced paracrine/autocrine effect that plays a role in tissue physiology and homeostasis. A change in local balance of RAS components will consequently lead to pathophysiological consequences.

Using transcriptomics meta-analysis, we have recently established the atlas of tissue RAS, which includes the transcriptional maps of RAS in 23 normal human tissues $[7,122]$. The maps provide information on the favored pathways of RAS in each tissue, but also on the co-expression of RAS genes, which may provide the basis for the discovery of potential regulatory mechanisms involved in the global expression of RAS components at the tissue level. In this regard, we have recently created the transcriptional maps of RAS in normal and atherosclerotic vascular wall showing the differences in angiotensin metabolism between both tissues [123]. Also, by analyzing the promoters of co-expressed genes, we identified potential transcription factors that could play a role in the global expression of RAS components in atheroma. Therefore, the atlas needs to be extended and studied at the protein level. In addition, RAS maps should be established from studies on each tissue under pathophysiological conditions, which will help understand the way the system is altered in each tissue under specific conditions, and thus, a better understanding of the mechanisms by which the system is involved in local tissue pathophysiology.

Funding: This work was supported by grants to KZ from Coopération pour l'Évaluation et le Développement de la Recherche (CEDRE), the Lebanese National Council for Scientific Research (CNRS) and Lebanese University grants. A.N. was awarded a scholarship from "La Nouvelle Société Francophone d'Athérosclérose" (NSFA).

Conflicts of Interest: The authors declare no conflict of interest.

\section{References}

1. Bader, M. Tissue renin-angiotensin-aldosterone systems: Targets for pharmacological therapy. Annu. Rev. Pharmacol. Toxicol. 2010, 50, 439-465. [CrossRef] [PubMed]

2. Ribeiro-Oliveira, A.; Nogueira, A.I.; Pereira, R.M.; Boas, W.W.V.; dos Santos, R.A.S.; e Silva, A.C.S. The renin-angiotensin system and diabetes: An update. Vasc. Health Risk Manag. 2008, 4, 787-803. [PubMed]

3. Nehme, A.; Zibara, K. Cellular distribution and interaction between extended renin-angiotensin-aldosterone system pathways in atheroma. Atherosclerosis 2017, 263, 334-342. [CrossRef]

4. Nehme, A.; Zibara, K. Efficiency and specificity of RAAS inhibitors in cardiovascular diseases: How to achieve better end-organ protection? Hypertens. Res. 2017, 40, 903-909. [CrossRef] [PubMed] 
5. Borghi, C.; SIIA Task Force; Rossi, F.; SIF Task Force. Role of the Renin-Angiotensin-Aldosterone System and Its Pharmacological Inhibitors in Cardiovascular Diseases: Complex and Critical Issues. High Blood Press Cardiovasc. Prev. 2015, 22, 429-444. [CrossRef] [PubMed]

6. Deschepper, C.F. Angiotensinogen: Hormonal regulation and relative importance in the generation of angiotensin II. Kidney Int. 1994, 46, 1561-1563. [CrossRef] [PubMed]

7. Nehme, A.; Cerutti, C.; Dhaouadi, N.; Gustin, M.P.; Courand, P.-Y.; Zibara, K.; Bricca, G. Atlas of tissue renin-angiotensin-aldosterone system in human: A transcriptomic meta-analysis. Sci Rep 2015, 5, 10035. [CrossRef]

8. Atlas, S.A. The renin-angiotensin aldosterone system: Pathophysiological role and pharmacologic inhibition. J. Manag. Care Pharm. 2007, 13, 9-20. [CrossRef] [PubMed]

9. Dzau, V.J.; Herrmann, H.C. Hormonal control of angiotensinogen production. Life Sci. 1982, 30, 577-584. [CrossRef]

10. Hsueh, W.A. Potential effects of renin activation on the regulation of renin production. Am. J. Physiol. 1984, 247, F205-F212. [CrossRef]

11. Kohlstedt, K.; Busse, R.; Fleming, I. Signaling via the angiotensin-converting enzyme enhances the expression of cyclooxygenase-2 in endothelial cells. Hypertension 2005, 45, 126-132. [CrossRef] [PubMed]

12. Gasparo, M.; de Catt, K.J.; Inagami, T.; Wright, J.W.; Unger, T. International Union of Pharmacology. XXIII. The Angiotensin II Receptors. Pharmacol. Rev. 2000, 52, 415-472.

13. Kim, S.; Iwao, H. Molecular and Cellular Mechanisms of Angiotensin II-Mediated Cardiovascular and Renal Diseases. Pharmacol. Rev. 2000, 52, 11-34. [PubMed]

14. Jaffe, I.Z.; Mendelsohn, M.E. Angiotensin II and aldosterone regulate gene transcription via functional mineralocortocoid receptors in human coronary artery smooth muscle cells. Circ. Res. 2005, 96, 643-650. [CrossRef] [PubMed]

15. Bhargava, A.; Wang, J.; Pearce, D. Regulation of epithelial ion transport by aldosterone through changes in gene expression. Mol. Cell. Endocrinol. 2004, 217, 189-196. [CrossRef]

16. Verhovez, A.; Williams, T.A.; Morello, F.; Monticone, S.; Brizzi, M.F.; Dentelli, P.; Fallo, F.; Fabris, B.; Amenta, F.; Gomez-Sanchez, C.; et al. Aldosterone does not modify gene expression in human endothelial cells. Horm. Metab. Res. 2012, 44, 234-238. [CrossRef] [PubMed]

17. Ferrario, C.M.; Ahmad, S.; Nagata, S.; Simington, S.W.; Varagic, J.; Kon, N.; Dell'italia, L.J. An evolving story of angiotensin-II-forming pathways in rodents and humans. Clin. Sci. 2014, 126, 461-469. [CrossRef]

18. Ganten, D.; Minnich, J.L.; Granger, P.; Hayduk, K.; Brecht, H.M.; Barbeau, A.; Boucher, R.; Genest, J. Angiotensin-forming enzyme in brain tissue. Science 1971, 173, 64-65. [CrossRef] [PubMed]

19. Husain, A.; Bumpus, F.M.; Smeby, R.R.; Brosnihan, K.B.; Khosla, M.C.; Speth, R.C.; Ferrario, C.M. Evidence for the existence of a family of biologically active angiotensin I-like peptides in the dog central nervous system. Circ. Res. 1983, 52, 460-464. [CrossRef] [PubMed]

20. Nguyen, G.; Delarue, F.; Burcklé, C.; Bouzhir, L.; Giller, T.; Sraer, J.-D. Pivotal role of the renin/prorenin receptor in angiotensin II production and cellular responses to renin. J. Clin. Invest. 2002, 109, 1417-1427. [CrossRef]

21. Paul, M.; Mehr, A.P.; Kreutz, R. Physiology of Local Renin-Angiotensin Systems. Physiol. Rev. 2006, 86, 747-803. [CrossRef] [PubMed]

22. Lau, T.; Carlsson, P.-O.; Leung, P.S. Evidence for a local angiotensin-generating system and dose-dependent inhibition of glucose-stimulated insulin release by angiotensin II in isolated pancreatic islets. Diabetologia 2004, 47, 240-248. [CrossRef] [PubMed]

23. Dzau, V.J. Circulating versus local renin-angiotensin system in cardiovascular homeostasis. Circulation 1988, 77, I4-I13. [PubMed]

24. Dzau, V.J. Tissue renin-angiotensin system in myocardial hypertrophy and failure. Arch. Intern. Med. 1993, 153, 937-942. [CrossRef] [PubMed]

25. Wu, C.; Lu, H.; Cassis, L.A.; Daugherty, A. Molecular and Pathophysiological Features of Angiotensinogen: A Mini Review. N. Am. J. Med. Sci. (Boston) 2011, 4, 183-190. [CrossRef]

26. Batenburg, W.W.; Danser, A.H.J. (Pro)renin and its receptors: Pathophysiological implications. Clin. Sci. 2012, 123, 121-133. [CrossRef] [PubMed]

27. Kaneshiro, Y.; Ichihara, A.; Sakoda, M.; Takemitsu, T.; Nabi, A.H.M.N.; Uddin, M.N.; Nakagawa, T.; Nishiyama, A.; Suzuki, F.; Inagami, T.; et al. Slowly progressive, angiotensin II-independent 
glomerulosclerosis in human (pro)renin receptor-transgenic rats. J. Am. Soc. Nephrol. 2007, 18, 1789-1795. [CrossRef] [PubMed]

28. Lutterotti, N.; von Catanzaro, D.F.; Sealey, J.E.; Laragh, J.H. Renin is not synthesized by cardiac and extrarenal vascular tissues. A review of experimental evidence. Circulation 1994, 89, 458-470. [CrossRef]

29. Boddi, M.; Poggesi, L.; Coppo, M.; Zarone, N.; Sacchi, S.; Tania, C.; Neri Serneri, G.G. Human vascular renin-angiotensin system and its functional changes in relation to different sodium intakes. Hypertension 1998, 31, 836-842. [CrossRef]

30. Neri Serneri, G.G.; Boddi, M.; Coppo, M.; Chechi, T.; Zarone, N.; Moira, M.; Poggesi, L.; Margheri, M.; Simonetti, I. Evidence for the existence of a functional cardiac renin-angiotensin system in humans. Circulation 1996, 94, 1886-1893. [CrossRef]

31. Cassis, L.A.; Police, S.B.; Yiannikouris, F.; Thatcher, S.E. Local adipose tissue renin-angiotensin system. Curr. Hypertens. Rep. 2008, 10, 93-98. [CrossRef]

32. Santos, C.F.; Akashi, A.E.; Dionísio, T.J.; Sipert, C.R.; Didier, D.N.; Greene, A.S.; Oliveira, S.H.P.; Pereira, H.J.V.; Becari, C.; Oliveira, E.B.; et al. Characterization of a local renin-angiotensin system in rat gingival tissue. J. Periodontol. 2009, 80, 130-139. [CrossRef] [PubMed]

33. Saris, J.J.; Derkx, F.H.; De Bruin, R.J.; Dekkers, D.H.; Lamers, J.M.; Saxena, P.R.; Schalekamp, M.A.; Jan Danser, A.H. High-affinity prorenin binding to cardiac man-6-P/IGF-II receptors precedes proteolytic activation to renin. Am. J. Physiol. Heart Circ. Physiol. 2001, 280, H1706-H1715. [CrossRef] [PubMed]

34. Morris, B.J.; Reid, I.A. A "Renin-Like" Enzymatic Action of Cathepsin D and the Similarity in Subcellular Distributions of "Renin-Like" Activity and Cathepsin D in the Midbrain of Dogs. Endocrinology 1978, 103, 1289-1296. [CrossRef] [PubMed]

35. Rakoczy, P.E.; Sarks, S.H.; Daw, N.; Constable, I.J. Distribution of cathepsin D in human eyes with or without age-related maculopathy. Exp. Eye Res. 1999, 69, 367-374. [CrossRef] [PubMed]

36. Naseem, R.H.; Hedegard, W.; Henry, T.D.; Lessard, J.; Sutter, K.; Katz, S.A. Plasma cathepsin D isoforms and their active metabolites increase after myocardial infarction and contribute to plasma renin activity. Basic Res. Cardiol. 2005, 100, 139-146. [CrossRef] [PubMed]

37. Lavrentyev, E.N.; Estes, A.M.; Malik, K.U. Mechanism of high glucose induced angiotensin II production in rat vascular smooth muscle cells. Circ. Res. 2007, 101, 455-464. [CrossRef] [PubMed]

38. Belova, L.A. Angiotensin II-generating enzymes. Biochemistry Mosc. 2000, 65, 1337-1345. [CrossRef] [PubMed]

39. Hackenthal, E.; Hackenthal, R.; Hilgenfeldt, U. Isorenin, pseudorenin, cathepsin D and renin. A comparative enzymatic study of angiotensin-forming enzymes. Biochim. Biophys. Acta 1978, 522, 574-588. [CrossRef]

40. Figueiredo, A.F.; Takii, Y.; Tsuji, H.; Kato, K.; Inagami, T. Rat kidney renin and cathepsin D: Purification and comparison of properties. Biochemistry 1983, 22, 5476-5481. [CrossRef]

41. Nagata, S.; Kato, J.; Sasaki, K.; Minamino, N.; Eto, T.; Kitamura, K. Isolation and identification of proangiotensin-12, a possible component of the renin-angiotensin system. Biochem. Biophys. Res. Commun. 2006, 350, 1026-1031. [CrossRef] [PubMed]

42. Komatsu, Y.; Kida, N.; Nozaki, N.; Kuwasako, K.; Nagata, S.; Kitamura, K.; Kato, J. Effects of proangiotensin-12 infused continuously over 14 days in conscious rats. Eur. J. Pharmacol. 2012, 683, 186-189. [CrossRef]

43. Ferrario, C.M.; Von Cannon, J.; Jiao, Y.; Ahmad, S.; Bader, M.; Dell'Italia, L.J.; Groban, L.; Varagic, J. Cardiac angiotensin-(1-12) expression and systemic hypertension in rats expressing the human angiotensinogen gene. Am. J. Physiol. Heart Circ. Physiol. 2016, 310, H995-H1002. [CrossRef] [PubMed]

44. Isa, K.; García-Espinosa, M.A.; Arnold, A.C.; Pirro, N.T.; Tommasi, E.N.; Ganten, D.; Chappell, M.C.; Ferrario, C.M.; Diz, D.I. Chronic immunoneutralization of brain angiotensin-(1-12) lowers blood pressure in transgenic (mRen2)27 hypertensive rats. Am. J. Physiol. Regul. Integr. Comp. Physiol. 2009, 297, R111-R115. [CrossRef]

45. Arnold, A.C.; Isa, K.; Shaltout, H.A.; Nautiyal, M.; Ferrario, C.M.; Chappell, M.C.; Diz, D.I. Angiotensin-(1-12) requires angiotensin converting enzyme and AT1 receptors for cardiovascular actions within the solitary tract nucleus. Am. J. Physiol. Heart Circ. Physiol. 2010, 299, H763-H771. [CrossRef]

46. Chitravanshi, V.C.; Sapru, H.N. Cardiovascular responses elicited by a new endogenous angiotensin in the nucleus tractus solitarius of the rat. Am. J. Physiol. Heart Circ. Physiol. 2011, 300, H230-H240. [CrossRef] [PubMed] 
47. Chitravanshi, V.C.; Proddutur, A.; Sapru, H.N. Cardiovascular actions of angiotensin-(1-12) in the hypothalamic paraventricular nucleus of the rat are mediated via angiotensin II. Exp. Physiol. 2012, 97, 1001-1017. [CrossRef]

48. Jessup, J.A.; Trask, A.J.; Chappell, M.C.; Nagata, S.; Kato, J.; Kitamura, K.; Ferrario, C.M. Localization of the novel angiotensin peptide, angiotensin-(1-12), in heart and kidney of hypertensive and normotensive rats. Am. J. Physiol. Heart Circ. Physiol. 2008, 294, H2614-H2618. [CrossRef]

49. Nagata, S.; Kato, J.; Kuwasako, K.; Kitamura, K. Plasma and tissue levels of proangiotensin-12 and components of the renin-angiotensin system (RAS) following low- or high-salt feeding in rats. Peptides 2010, 31, 889-892. [CrossRef] [PubMed]

50. Westwood, B.M.; Chappell, M.C. Divergent pathways for the angiotensin-(1-12) metabolism in the rat circulation and kidney. Peptides 2012, 35, 190-195. [CrossRef] [PubMed]

51. Ahmad, S.; Varagic, J.; Westwood, B.M.; Chappell, M.C.; Ferrario, C.M. Uptake and metabolism of the novel peptide angiotensin-(1-12) by neonatal cardiac myocytes. PLoS ONE 2011, 6, e15759. [CrossRef]

52. Ahmad, S.; Simmons, T.; Varagic, J.; Moniwa, N.; Chappell, M.C.; Ferrario, C.M. Chymase-dependent generation of angiotensin II from angiotensin-(1-12) in human atrial tissue. PLoS ONE 2011, 6, e28501. [CrossRef]

53. Prosser, H.C.; Richards, A.M.; Forster, M.E.; Pemberton, C.J. Regional vascular response to ProAngiotensin-12 (PA12) through the rat arterial system. Peptides 2010, 31, 1540-1545. [CrossRef] [PubMed]

54. Tonnesen, M.G.; Klempner, M.S.; Austen, K.F.; Wintroub, B.U. Identification of a human neutrophil angiotension II-generating protease as cathepsin G. J. Clin. Invest. 1982, 69, 25-30. [CrossRef]

55. Urata, H.; Kinoshita, A.; Misono, K.S.; Bumpus, F.M.; Husain, A. Identification of a highly specific chymase as the major angiotensin II-forming enzyme in the human heart. J. Biol. Chem. 1990, 265, 22348-22357. [PubMed]

56. Park, S.; Bivona, B.J.; Kobori, H.; Seth, D.M.; Chappell, M.C.; Lazartigues, E.; Harrison-Bernard, L.M. Major role for ACE-independent intrarenal ANG II formation in type II diabetes. Am. J. Physiol. Renal Physiol. 2010, 298, F37-F48. [CrossRef] [PubMed]

57. Nouet, S.; Nahmias, C. Signal transduction from the angiotensin II AT2 receptor. Trends Endocrinol. Metab. 2000, 11, 1-6. [CrossRef]

58. Fei, D.T.; Coghlan, J.P.; Fernley, R.T.; Scoggins, B.A.; Tregear, G.W. Peripheral production of angiotensin II and III in sheep. Circ. Res. 1980, 46, I135-I137.

59. Van Kats, J.P.; van Meegen, J.R.; Verdouw, P.D.; Duncker, D.J.; Schalekamp, M.A.; Danser, A.H. Subcellular localization of angiotensin II in kidney and adrenal. J. Hypertens. 2001, 19, 583-589. [CrossRef] [PubMed]

60. Van Kats, J.P.; Danser, A.H.; van Meegen, J.R.; Sassen, L.M.; Verdouw, P.D.; Schalekamp, M.A. Angiotensin production by the heart: A quantitative study in pigs with the use of radiolabeled angiotensin infusions. Circulation 1998, 98, 73-81. [CrossRef]

61. Danser, A.H.; van Kats, J.P.; Verdouw, P.D.; Schalekamp, M.A. Evidence for the existence of a functional cardiac renin-angiotensin system in humans. Circulation 1997, 96, 3795-3796. [PubMed]

62. Sealey, J.E. Evidence for cardiovascular effects of prorenin. J. Hum. Hypertens. 1995, 9, 381-384.

63. Esther, C.R.; Marino, E.M.; Howard, T.E.; Machaud, A.; Corvol, P.; Capecchi, M.R.; Bernstein, K.E. The critical role of tissue angiotensin-converting enzyme as revealed by gene targeting in mice. J. Clin. Invest. 1997, 99, 2375-2385. [CrossRef]

64. Arakawa, K.; Ikeda, M.; Fukuyama, J.; Sakai, T. A pressor formation by trypsin from renin-denatured human plasma protein. J. Clin. Endocrinol. Metab. 1976, 42, 599-602. [CrossRef]

65. Arakawa, K.; Maruta, H. Ability of kallikrein to generate angiotensin II-like pressor substance and a proposed 'kinin-tensin enzyme system'. Nature 1980, 288, 705-706. [CrossRef] [PubMed]

66. Miura, S.; Ideishi, M.; Sakai, T.; Motoyama, M.; Kinoshita, A.; Sasaguri, M.; Tanaka, H.; Shindo, M.; Arakawa, K. Angiotensin II formation by an alternative pathway during exercise in humans. J. Hypertens. 1994, 12, 1177-1181. [CrossRef] [PubMed]

67. Arakawa, K.; Urata, H. Hypothesis regarding the pathophysiological role of alternative pathways of angiotensin II formation in atherosclerosis. Hypertension 2000, 36, 638-641. [CrossRef] [PubMed]

68. Li, Y.; Li, X.-H.; Yuan, H. Angiotensin II type-2 receptor-specific effects on the cardiovascular system. Cardiovasc. Diagn. Ther. 2012, 2, 56-62. [PubMed] 
69. Carey, R.M.; Wang, Z.Q.; Siragy, H.M. Update: Role of the angiotensin type-2 (AT(2)) receptor in blood pressure regulation. Curr. Hypertens. Rep. 2000, 2, 198-201. [CrossRef] [PubMed]

70. Jin, X.H.; Wang, Z.Q.; Siragy, H.M.; Guerrant, R.L.; Carey, R.M. Regulation of jejunal sodium and water absorption by angiotensin subtype receptors. Am. J. Physiol. 1998, 275, R515-R523. [CrossRef]

71. Strauss, M.H.; Hall, A.S. Angiotensin Receptor Blockers May Increase Risk of Myocardial Infarction. Circulation 2006, 114, 838-854. [CrossRef]

72. Reudelhuber, T.L. The continuing saga of the AT2 receptor: A case of the good, the bad, and the innocuous. Hypertension 2005, 46, 1261-1262. [CrossRef]

73. Pahlavani, M.; Kalupahana, N.S.; Ramalingam, L.; Moustaid-Moussa, N. Regulation and Functions of the Renin-Angiotensin System in White and Brown Adipose Tissue. Compr Physiol 2017, 7, 1137-1150.

74. Tonnaer, J.A.; Engels, G.M.; Wiegant, V.M.; Burbach, J.P.; De Jong, W.; De Wied, D. Proteolytic conversion of angiotensins in rat brain tissue. Eur. J. Biochem. 1983, 131, 415-421. [CrossRef]

75. Santos, R.A.; Brosnihan, K.B.; Chappell, M.C.; Pesquero, J.; Chernicky, C.L.; Greene, L.J.; Ferrario, C.M. Converting enzyme activity and angiotensin metabolism in the dog brainstem. Hypertension 1988, 11, I153-I157. [CrossRef]

76. Tom, B.; Dendorfer, A.; Danser, A.H.J. Bradykinin, angiotensin-(1-7), and ACE inhibitors: How do they interact? Int. J. Biochem. Cell Biol. 2003, 35, 792-801. [CrossRef]

77. Donoghue, M.; Hsieh, F.; Baronas, E.; Godbout, K.; Gosselin, M.; Stagliano, N.; Donovan, M.; Woolf, B.; Robison, K.; Jeyaseelan, R.; et al. A novel angiotensin-converting enzyme-related carboxypeptidase (ACE2) converts angiotensin I to angiotensin 1-9. Circ. Res. 2000, 87, E1-E9. [CrossRef]

78. Tipnis, S.R.; Hooper, N.M.; Hyde, R.; Karran, E.; Christie, G.; Turner, A.J. A Human Homolog of Angiotensin-converting Enzyme CLONING AND FUNCTIONAL EXPRESSION AS A CAPTOPRIL-INSENSITIVE CARBOXYPEPTIDASE. J. Biol. Chem. 2000, 275, 33238-33243. [CrossRef]

79. Rice, G.I.; Thomas, D.A.; Grant, P.J.; Turner, A.J.; Hooper, N.M. Evaluation of angiotensin-converting enzyme (ACE), its homologue ACE2 and neprilysin in angiotensin peptide metabolism. Biochem. J. 2004, 383, 45-51. [CrossRef]

80. Jackman, H.L.; Massad, M.G.; Sekosan, M.; Tan, F.; Brovkovych, V.; Marcic, B.M.; Erdös, E.G. Angiotensin 1-9 and 1-7 release in human heart: Role of cathepsin A. Hypertension 2002, 39, 976-981. [CrossRef]

81. Pereira, M.G.A.G.; Souza, L.L.; Becari, C.; Duarte, D.A.; Camacho, F.R.B.; Oliveira, J.A.C.; Gomes, M.D.; Oliveira, E.B.; Salgado, M.C.O.; Garcia-Cairasco, N.; et al. Angiotensin II-independent angiotensin-(1-7) formation in rat hippocampus: Involvement of thimet oligopeptidase. Hypertension 2013, 62, 879-885. [CrossRef]

82. Douglas, G.C.; O’Bryan, M.K.; Hedger, M.P.; Lee, D.K.L.; Yarski, M.A.; Smith, A.I.; Lew, R.A. The novel angiotensin-converting enzyme (ACE) homolog, ACE2, is selectively expressed by adult Leydig cells of the testis. Endocrinology 2004, 145, 4703-4711. [CrossRef]

83. Santos, R.A.S.; Simoes e Silva, A.C.; Maric, C.; Silva, D.M.R.; Machado, R.P.; de Buhr, I.; Heringer-Walther, S.; Pinheiro, S.V.B.; Lopes, M.T.; Bader, M.; et al. Angiotensin-(1-7) is an endogenous ligand for the G protein-coupled receptor Mas. Proc. Natl. Acad. Sci. USA 2003, 100, 8258-8263. [CrossRef] [PubMed]

84. Simões e Silva, A.C.; Silveira, K.D.; Ferreira, A.J.; Teixeira, M.M. ACE2, angiotensin-(1-7) and Mas receptor axis in inflammation and fibrosis. Br. J. Pharmacol. 2013, 169, 477-492. [CrossRef] [PubMed]

85. Kostenis, E.; Milligan, G.; Christopoulos, A.; Sanchez-Ferrer, C.F.; Heringer-Walther, S.; Sexton, P.M.; Gembardt, F.; Kellett, E.; Martini, L.; Vanderheyden, P.; et al. G-protein-coupled receptor Mas is a physiological antagonist of the angiotensin II type 1 receptor. Circulation 2005, 111, 1806-1813. [CrossRef] [PubMed]

86. Villela, D.; Leonhardt, J.; Patel, N.; Joseph, J.; Kirsch, S.; Hallberg, A.; Unger, T.; Bader, M.; Santos, R.A.; Sumners, C.; et al. Angiotensin type 2 receptor (AT2R) and receptor Mas: A complex liaison. Clin. Sci. 2015, 128, 227-234. [CrossRef] [PubMed]

87. Karnik, S.S.; Khuraijam, D.; Tirupula, K.; Unal, H. Significance of Ang(1-7) coupling with MAS1 and other GPCRs to the Renin-Angiotensin System: IUPHAR Review " $X$ ". Br. J. Pharmacol. 2017. [CrossRef]

88. Chappell, M.C. Emerging evidence for a functional angiotensin-converting enzyme 2-angiotensin-(1-7)-MAS receptor axis: More than regulation of blood pressure? Hypertension 2007, 50, 596-599. [CrossRef] [PubMed] 
89. Oudit, G.Y.; Kassiri, Z.; Patel, M.P.; Chappell, M.; Butany, J.; Backx, P.H.; Tsushima, R.G.; Scholey, J.W.; Khokha, R.; Penninger, J.M. Angiotensin II-mediated oxidative stress and inflammation mediate the age-dependent cardiomyopathy in ACE2 null mice. Cardiovasc. Res. 2007, 75, 29-39. [CrossRef]

90. Liu, R.; Qi, H.; Wang, J.; Wang, Y.; Cui, L.; Wen, Y.; Yin, C. Angiotensin-converting enzyme (ACE and ACE2) imbalance correlates with the severity of cerulein-induced acute pancreatitis in mice. Exp. Physiol. 2014, 99, 651-663. [CrossRef]

91. Wösten-van Asperen, R.M.; Lutter, R.; Specht, P.A.; Moll, G.N.; van Woensel, J.B.; van der Loos, C.M.; van Goor, H.; Kamilic, J.; Florquin, S.; Bos, A.P. Acute respiratory distress syndrome leads to reduced ratio of ACE/ACE2 activities and is prevented by angiotensin-(1-7) or an angiotensin II receptor antagonist. J. Pathol. 2011, 225, 618-627. [CrossRef]

92. Simões e Silva, A.C.; Miranda, A.S.; Rocha, N.P.; Teixeira, A.L. Renin angiotensin system in liver diseases: Friend or foe? World J. Gastroenterol. 2017, 23, 3396-3406. [CrossRef]

93. Moreira de Macêdo, S.; Guimarães, T.A.; Feltenberger, J.D.; Sousa Santos, S.H. The role of renin-angiotensin system modulation on treatment and prevention of liver diseases. Peptides 2014, 62, 189-196. [CrossRef]

94. Shim, K.Y.; Eom, Y.W.; Kim, M.Y.; Kang, S.H.; Baik, S.K. Role of the renin-angiotensin system in hepatic fibrosis and portal hypertension. Korean J. Intern. Med. 2018, 33, 453-461. [CrossRef]

95. Mak, K.Y.; Chin, R.; Cunningham, S.C.; Habib, M.R.; Torresi, J.; Sharland, A.F.; Alexander, I.E.; Angus, P.W.; Herath, C.B. ACE2 Therapy Using Adeno-associated Viral Vector Inhibits Liver Fibrosis in Mice. Mol. Ther. 2015, 23, 1434-1443. [CrossRef]

96. Osterreicher, C.H.; Taura, K.; De Minicis, S.; Seki, E.; Penz-Osterreicher, M.; Kodama, Y.; Kluwe, J.; Schuster, M.; Oudit, G.Y.; Penninger, J.M.; et al. Angiotensin-converting-enzyme 2 inhibits liver fibrosis in mice. Hepatology 2009, 50, 929-938. [CrossRef] [PubMed]

97. Saldanha da Silva, A.A.; Rodrigues Prestes, T.R.; Lauar, A.O.; Finotti, B.B.; Simoes, E.; Silva, A.C. Renin Angiotensin System and Cytokines in Chronic Kidney Disease: Clinical and Experimental Evidence. Protein Pept. Lett. 2017, 24, 799-808. [CrossRef]

98. Caruso-Neves, C.; Lara, L.S.; Rangel, L.B.; Grossi, A.L.; Lopes, A.G. Angiotensin-(1-7) modulates the ouabain-insensitive Na+-ATPase activity from basolateral membrane of the proximal tubule. Biochim. Biophys. Acta 2000, 1467, 189-197. [CrossRef]

99. Lara, L.S.; Bica, R.B.S.; Sena, S.L.F.; Correa, J.S.; Marques-Fernandes, M.F.; Lopes, A.G.; Caruso-Neves, C. Angiotensin-(1-7) reverts the stimulatory effect of angiotensin II on the proximal tubule $\mathrm{Na}(+)$-ATPase activity via a A779-sensitive receptor. Regul. Pept. 2002, 103, 17-22. [CrossRef]

100. Esteban, V.; Heringer-Walther, S.; Sterner-Kock, A.; de Bruin, R.; van den Engel, S.; Wang, Y.; Mezzano, S.; Egido, J.; Schultheiss, H.-P.; Ruiz-Ortega, M.; et al. Angiotensin-(1-7) and the g protein-coupled receptor MAS are key players in renal inflammation. PLoS ONE 2009, 4, e5406. [CrossRef]

101. Jiang, T.; Gao, L.; Guo, J.; Lu, J.; Wang, Y.; Zhang, Y. Suppressing inflammation by inhibiting the NF-kB pathway contributes to the neuroprotective effect of angiotensin-(1-7) in rats with permanent cerebral ischaemia. Br. J. Pharmacol. 2012, 167, 1520-1532. [CrossRef]

102. Chiu, A.T.; Ryan, J.W.; Stewart, J.M.; Dorer, F.E. Formation of angiotensin III by angiotensin-converting enzyme. Biochem. J. 1976, 155, 189-192. [CrossRef]

103. Cesari, M.; Rossi, G.P.; Pessina, A.C. Biological properties of the angiotensin peptides other than angiotensin II: Implications for hypertension and cardiovascular diseases. J. Hypertens. 2002, 20, 793-799. [CrossRef]

104. Padia, S.H.; Kemp, B.A.; Howell, N.L.; Siragy, H.M.; Fournie-Zaluski, M.-C.; Roques, B.P.; Carey, R.M. Intrarenal aminopeptidase $\mathrm{N}$ inhibition augments natriuretic responses to angiotensin III in angiotensin type 1 receptor-blocked rats. Hypertension 2007, 49, 625-630. [CrossRef]

105. Kotlo, K.; Hughes, D.E.; Herrera, V.L.M.; Ruiz-Opazo, N.; Costa, R.H.; Robey, R.B.; Danziger, R.S. Functional polymorphism of the Anpep gene increases promoter activity in the Dahl salt-resistant rat. Hypertension 2007, 49, 467-472. [CrossRef] [PubMed]

106. Carrera, M.P.; Ramírez-Expósito, M.J.; Valenzuela, M.T.; Dueñas, B.; García, M.J.; Mayas, M.D.; Martínez-Martos, J.M. Renin-angiotensin system-regulating aminopeptidase activities are modified in the pineal gland of rats with breast cancer induced by N-methyl-nitrosourea. Cancer Invest. 2006, 24, 149-153. [CrossRef]

107. Chai, S.Y.; Fernando, R.; Peck, G.; Ye, S.-Y.; Mendelsohn, F.A.O.; Jenkins, T.A.; Albiston, A.L. The angiotensin IV/AT4 receptor. Cell. Mol. Life Sci. 2004, 61, 2728-2737. [CrossRef] [PubMed] 
108. Appenrodt, E.; Brattström, A. Effects of central angiotensin II and angiotensin III on baroreflex regulation. Neuropeptides 1994, 26, 175-180. [CrossRef]

109. Handa, R.K. Biphasic actions of angiotensin IV on renal blood flow in the rat. Regul. Pept. 2006, 136, $23-29$. [CrossRef] [PubMed]

110. Albiston, A.L.; McDowall, S.G.; Matsacos, D.; Sim, P.; Clune, E.; Mustafa, T.; Lee, J.; Mendelsohn, F.A.; Simpson, R.J.; Connolly, L.M.; et al. Evidence that the angiotensin IV (AT(4)) receptor is the enzyme insulin-regulated aminopeptidase. J. Biol. Chem. 2001, 276, 48623-48626. [CrossRef] [PubMed]

111. Lochard, N.; Thibault, G.; Silversides, D.W.; Touyz, R.M.; Reudelhuber, T.L. Chronic production of angiotensin IV in the brain leads to hypertension that is reversible with an angiotensin II AT1 receptor antagonist. Circ. Res. 2004, 94, 1451-1457. [CrossRef]

112. Li, X.C.; Campbell, D.J.; Ohishi, M.; Yuan, S.; Zhuo, J.L. AT1 receptor-activated signaling mediates angiotensin IV-induced renal cortical vasoconstriction in rats. Am. J. Physiol. Renal Physiol. 2006, 290, F1024-F1033. [CrossRef] [PubMed]

113. Jankowski, V.; Vanholder, R.; van der Giet, M.; Tölle, M.; Karadogan, S.; Gobom, J.; Furkert, J.; Oksche, A.; Krause, E.; Tran, T.N.A.; et al. Mass-spectrometric identification of a novel angiotensin peptide in human plasma. Arterioscler. Thromb. Vasc. Biol. 2007, 27, 297-302. [CrossRef]

114. Yang, R.; Smolders, I.; Vanderheyden, P.; Demaegdt, H.; Van Eeckhaut, A.; Vauquelin, G.; Lukaszuk, A.; Tourwé, D.; Chai, S.Y.; Albiston, A.L.; et al. Pressor and renal hemodynamic effects of the novel angiotensin A peptide are angiotensin II type 1A receptor dependent. Hypertension 2011, 57, 956-964. [CrossRef] [PubMed]

115. Coutinho, D.C.O.; Foureaux, G.; Rodrigues, K.D.L.; Salles, R.L.A.; Moraes, P.L.; Murça, T.M.; De Maria, M.L.A.; Gomes, E.R.M.; Santos, R.A.S.; Guatimosim, S.; et al. Cardiovascular effects of angiotensin A: A novel peptide of the renin-angiotensin system. J. Renin. Angiotensin Aldosterone Syst. 2014, 15, 480-486. [CrossRef] [PubMed]

116. Lautner, R.Q.; Villela, D.C.; Fraga-Silva, R.A.; Silva, N.; Verano-Braga, T.; Costa-Fraga, F.; Jankowski, J.; Jankowski, V.; Sousa, F.; Alzamora, A.; et al. Discovery and characterization of alamandine: A novel component of the renin-angiotensin system. Circ. Res. 2013, 112, 1104-1111. [CrossRef]

117. Tetzner, A.; Gebolys, K.; Meinert, C.; Klein, S.; Uhlich, A.; Trebicka, J.; Villacañas, Ó.; Walther, T. G-Protein-Coupled Receptor MrgD Is a Receptor for Angiotensin-(1-7) Involving Adenylyl Cyclase, cAMP, and Phosphokinase, A. Hypertension 2016, 68, 185-194. [CrossRef]

118. Habiyakare, B.; Alsaadon, H.; Mathai, M.L.; Hayes, A.; Zulli, A. Reduction of angiotensin A and alamandine vasoactivity in the rabbit model of atherogenesis: Differential effects of alamandine and Ang(1-7). Int. J. Exp. Pathol. 2014, 95, 290-295. [CrossRef] [PubMed]

119. Mogielnicki, A.; Kramkowski, K.; Hermanowicz, J.M.; Leszczynska, A.; Przyborowski, K.; Buczko, W. Angiotensin-(1-9) enhances stasis-induced venous thrombosis in the rat because of the impairment of fibrinolysis. J Renin. Angiotensin Aldosterone Syst. 2014, 15, 13-21. [CrossRef] [PubMed]

120. Karwowska-Polecka, W.; Kułakowska, A.; Wiśniewski, K.; Braszko, J.J. Losartan influences behavioural effects of angiotensin II(3-7) in rats. Pharmacol. Res. 1997, 36, 275-283. [CrossRef]

121. Handa, R.K. Metabolism alters the selectivity of angiotensin-(1-7) receptor ligands for angiotensin receptors. J. Am. Soc. Nephrol. 2000, 11, 1377-1386. [PubMed]

122. Nehme, A.; Marcelo, P.; Nasser, R.; Kobeissy, F.; Bricca, G.; Zibara, K. The kinetics of angiotensin-I metabolism in human carotid atheroma: An emerging role for angiotensin (1-7). Vascul. Pharmacol. 2016. [CrossRef] [PubMed]

123. Nehme, A.; Cerutti, C.; Zibara, K. Transcriptomic analysis reveals novel transcription factors associated with renin-angiotensin-aldosterone system in human atheroma. Hypertension 2016, 68, 1375-1384. [CrossRef]

(C) 2019 by the authors. Licensee MDPI, Basel, Switzerland. This article is an open access article distributed under the terms and conditions of the Creative Commons Attribution (CC BY) license (http://creativecommons.org/licenses/by/4.0/). 